\section{Combinations of Nitrogen Rates and Irrigation Programs for Tomato Production in Spodosols}

\author{
Bielinski M. Santos ${ }^{1}$
}

AdDitional INDEX wORDs. Solanum lycopersicum, crop nutrition, soil fertility, seepage, microirrigation, best management practices

\begin{abstract}
Summary. Two field studies were conducted to compare the effects of preplant nitrogen $(\mathrm{N})$ rates and irrigation programs on tomato (Solanum lycopersicum) growth and yields. Irrigation programs were seepage (subsurface) irrigation alone at a water volume of 28 acre-inches/acre per season and seepage plus drip irrigation at a volume of 28 and 14 acre-inches/acre per season, respectively. Preplant $N$ fertilization rates were 200,250 , and $300 \mathrm{lb}$ /acre, using ammonium nitrate as the $\mathrm{N}$ source. There were significant irrigation program by $\mathbf{N}$ rate interactions for nitrate $\left(\mathrm{NO}_{3}{ }^{-}\right)$petiole concentrations at 8 weeks after transplanting (WAT), and yield of extra-large fruit and total marketable fruit, but not for plant height at 5 and 7 WAT. The highest $\mathrm{NO}_{3}-\mathrm{N}$ petiole concentrations were found in plots treated with 200,250 , and $300 \mathrm{lb} /$ acre for $\mathrm{N}$ and seepage plus drip irrigation, and with $300 \mathrm{lb} /$ acre $\mathrm{N}$ under seepage irrigation alone. For the total marketable fruit weight, there were no differences among $\mathrm{N}$ rates in those plots irrigated with the seepage plus drip combination, ranging between 23.8 and 25.9 tons/acre. However, there was a significant $\mathrm{N}$ effect in plots receiving only seepage irrigation with marketable fruit weight almost doubling from 12.0 to 22.7 tons/acre when applying 200 and $300 \mathrm{lb} /$ acre $\mathrm{N}$, respectively. Both irrigation programs had equivalent performance when $300 \mathrm{lb} /$ acre $\mathrm{N}$ were applied.
\end{abstract}

$\mathrm{T}$ The fresh-market tomato is a leading vegetable crop throughout the world. In the United States, more than 125,000 acres were planted in 2007, representing almost $\$ 1.6$ billion in gross sales [U.S. Department of Agriculture (USDA), 2007]. Florida tomato production accounts for $\approx 37 \%$ of the gross sales in the United States (USDA, 2007), and the majority of the planted area is concentrated in the west-central and southwest part of the state. In Florida, tomato production occurs in sandy soils with rapid infiltration and high water tables. The nutrient-leaching potential of these soils is relatively high, which has important environmental and crop production implications. From the environmental standpoint, $\mathrm{NO}_{3}{ }^{-}$leaching to groundwaters is one of the main causes for eutrophication of rivers and lakes and subsequent changes in aquatic life, such as increased populations of phytoplankton and benthic and epiphytic algae, as well as reduction on harvestable fish and shellfish and coral reef communities [Carpenter et al., 1998; Finkl and

Gulf Coast Research and Education Center, IFAS, University of Florida, FL 33598

This research was possible due to funding provided by the Southwest Florida Water Management District.

${ }^{1}$ Corresponding author. E-mail: bmsantos@ufl.edu.
Charlier, 2003; Florida Department of Environmental Protection (FDEP), 2008; Florida Springs Task Force, 2000]. In many bodies of water across Florida, $\mathrm{NO}_{3}^{-}$levels have increased 2 - to 3 -fold over the past 20 years, reflecting the close link between surOne of the main sources of $\mathrm{NO}_{3}^{-}$in groundwaters is agricultural fertilizers (Carpenter et al., 1998). Therefore, reducing nutrient leaching through appropriate fertilization programs is a desired practice for tomato production and to support the current best management practice efforts in the state. From the crop production standpoint, fertilizer prices have steadily increased during the last few years as a result of the higher worldwide oil prices and transportation costs (USDA, 2009). face and groundwater (FDEP, 2008).
This situation forces tomato growers to seek for more effective ways to save on fertilizer costs.

Under current production practices, fresh-market tomato transplants are set in polyethylene-mulched beds and irrigated with seepage alone or a combination of seepage and drip irrigation (Olson et al., 2006; Simonne, 2004). Seepage irrigation, often called subsurface irrigation, is a common method in the muck and sandy soils of southern Florida and consists of elevating the water table through the use of lateral field ditches to allow upward water movement through capillarity in soils with an underlying impermeable layer (Simonne and Morgant, 2005). In this method, the water table is maintained between 18 and 24 inches deep by continuously providing water to the lateral ditches, regardless of the soil water volume fluctuations throughout the day. The water use efficiency of this method is very low because it uses large water volumes and it may not provide complete wetted fronts in planting beds (Bouman et al., 1994; Smajstrla et al., 2002). Stanley and Clark (2003) indicated that capillary rise from a perched water table is not sufficient to maintain a soil moisture content above $10 \%$ in the upper 6 inches of planting beds when the water table level is below 24 inches. Recent consultations among growers indicated that between 28 and 40 acreinches/acre of water are used for crop establishment and maintenance during the growing seasons in southwest and west-central Florida. This irrigation method is used in $\approx 44 \%$ of the planted acreage with vegetable and fruit crops in Florida (Smajstrla and Haman, 2005).

With drip irrigation, water is pressurized and delivered to the soil through tubes with uniformly spaced

\begin{tabular}{llll}
\hline $\begin{array}{l}\text { Units } \\
\begin{array}{l}\text { To convert U.S. to SI, } \\
\text { multiply by }\end{array}\end{array}$ & U.S. unit & SI unit & $\begin{array}{l}\text { To convert SI to U.S., } \\
\text { multiply by }\end{array}$ \\
\hline 0.4047 & acre $(\mathrm{s})$ & $\mathrm{ha}$ & 2.4711 \\
254.0000 & acre-inch/acre & $\mathrm{m}^{3} \cdot \mathrm{ha}^{-1}$ & 0.0039 \\
0.3048 & $\mathrm{ft}$ & $\mathrm{m}$ & 3.2808 \\
0.1242 & gal/100 ft & $\mathrm{L} \cdot \mathrm{m}^{-1}$ & 8.0520 \\
9.3540 & gal/acre & $\mathrm{L} \cdot \mathrm{ha}^{-1}$ & 0.1069 \\
2.54 & inch $(\mathrm{es})$ & $\mathrm{cm}$ & 0.3937 \\
1.1209 & lb/acre & $\mathrm{kg} \cdot \mathrm{ha}^{-1}$ & 0.8922 \\
0.0254 & mil & $\mathrm{mm}$ & 39.3701 \\
1 & ppm & $\mathrm{mg} \cdot \mathrm{kg}^{-1}$ & 1 \\
2.2417 & ton/acre & $\mathrm{t} \cdot \mathrm{ha}^{-1}$ & 0.4461
\end{tabular}


emitters that provide water near the crop root zone. This is a highly efficient irrigation system (between 90\% and $95 \%$ efficiency) because it provides small amounts of water on a frequent basis (Smajstrla et al., 2002). The appropriate scheduling of drip irrigation is necessary to maximize crop yields and to reduce nutrient leaching (Bar-Yosef, 1977). Some advantages of drip irrigation over other irrigation systems include: 1) significantly reducing water use, 2 ) reducing the incidence of diseases and weeds in dry row middles, 3 ) using smaller pumps to provide the necessary daily amounts of water, and 4) combining with fertilizers and certain pesticides with the irrigation water (Locascio, 2005). Although establishing drip irrigation is more expensive, it uses one-third the water volume of seepage with higher wetting efficiency in tomato production (Pitts et al., 2002). Current reference evapotranspiration values for westcentral Florida are between 15 and 16.4 acre-inches/acre per season during the fall (February to May) and the spring (August to November) tomato seasons (Simonne et al., 2007). However, a recent informal survey among growers indicated that there is a tendency to overirrigate the crop. Additionally, overirrigation is a common practice among growers to maintain a high water table in tomato fields even with drip irrigation (Simonne and Morgant, 2005).

Many growers apply up to 350 $\mathrm{lb} /$ acre of granular fertilizers containing $\mathrm{N}$ before covering planting beds with mulch. Thus, $\mathrm{NO}_{3}^{-}$leaching to groundwaters is one of the main water quality concerns in Florida. There is a significant discrepancy between the current $\mathrm{N}$ recommendations for tomato production in westcentral and southwest Florida, and the $\mathrm{N}$ applications made by most of the tomato growers in that part of the state. The current recommendation for tomatoes is $\approx 200 \mathrm{lb} /$ acre $\mathrm{N}$, assuming beds are on 6 - $\mathrm{ft}$ centers (7260 linear $\mathrm{ft}$ of beds per acre), regardless of irrigation type (Olson et al., 2006). Based on that recommendation, supplemental applications of $\mathrm{N}$ are used through the drip irrigation lines to compensate for leaching losses based on rainfall (Olson et al., 2006). Recent surveys in the Manatee-Ruskin production district indicated that grower standard applications average $\approx 300 \mathrm{lb} /$ acre $\mathrm{N}$ per season, regardless of whether beds are on 5- or 6- $\mathrm{ft}$ centers (7260 and 8712 linear $\mathrm{ft}$ of beds per acre, respectively). Growers feel that higher rates are required due to the more vigorous growth habit of today's varieties and longer cropping season. The use of two different irrigation systems complicates nutrient management because seepage irrigation rapidly solubilizes dry $\mathrm{N}$ fertilizers and, if managed inappropriately, it could increase the risks of $\mathrm{NO}_{3}{ }^{-}$ leaching to groundwaters. A similar result occurs when drip irrigation is used excessively. Therefore, irrigation practices could affect $\mathrm{N}$ usage in tomato fields. This study was designed to compare three $\mathrm{N}$ rates and four irrigation programs and their effects on tomato growth and yields.

\section{Materials and methods}

Two field trials were conducted in between Feb. and May 2006 and Mar. and June 2007 at the Gulf Coast Research and Education Center of the University of Florida in Balm. The soil at the experimental site is classified as a Myakka fine sand siliceous hyperthermic Oxyaquic Alorthod with $1.5 \%$ organic matter and a $\mathrm{pH}$ of 7.3. Planting beds were preformed with a standard bedder and were 32 inches wide at the base and 28 inches wide on top. Bed height was 8 inches. Beds were fumigated with methyl bromide plus chloropicrin $(67: 33, v / v)$ through three chisels spaced 12 inches apart, which delivered fumigant 6 inches deep. Soil fumigation occurred 3 weeks before transplanting. Within $1 \mathrm{~min}$ after fumigation, a drip irrigation tubing $(0.45 \mathrm{gal} / 100 \mathrm{ft}$ of bed per minute; T-Tape Systems International, San Diego, CA) was placed in all plots, regardless of irrigation program, 1 inch deep down the center of the bed, and planting beds were covered with 1-mil-thick silver on black mulch.

'Florida-47' tomato seedlings in the four true-leaf stage ( 8 inches tall) were planted $2 \mathrm{ft}$ apart in a single rows and 2 inches offset of bed centers on 23 Mar. 2006 and 8 Mar. 2007. During the $3 \mathrm{~d}$ before transplanting, the water table was maintained at 24 inches below the bed tops by providing constant seepage irrigation to maintain the experimental site at field capacity. The depth of the water table was monitored every $3 \mathrm{~d}$ by installing one observation well (36 inches long $\times 4$ inches in diameter) for every three planting beds. Each well was installed at the end of the selected plots and was buried up to bed tops. After transplanting, a water volume of 0.4 acre-inches/acre per day $(10,862$ gal/acre per day) applied through seepage was used for the first $10 \mathrm{~d}$ after transplanting to establish the young plants. This volume was constantly applied ( $24 \mathrm{~h}$ per day) through l-ft-deep irrigation ditches oriented along the mulched beds. The experimental site was set up to have one irrigation ditch for each three planting beds. After this period of tomato establishment, seepage water volumes were controlled with standard water meters and timers (Nelson Co., Peoria, IL) installed on each seepage spigot. These meters and timers allowed keeping a constant flow of $\approx 0.4$ acre-inches/acre per day, which is the normal production practice for tomato produce under seepage irrigation. Plots with seepage irrigation were physically separated by a $30-\mathrm{ft}$ wide buffer from those with seepage plus drip irrigation. In the treatments with drip irrigation, water was provided three times per day with irrigation cycles between 15 and $45 \mathrm{~min}$ (after $10 \mathrm{~min}$ of line pressurization), depending on the crop growth stage. Time adjustments to water volumes were made at 3 and 6 weeks after transplanting (WAT) to satisfy crop growing stage and evapotranspiration. Water volumes were monitored using the same water controllers previously described.

Six treatments resulted from combinations of irrigation and $\mathrm{N}$ fertilization programs. The two irrigation programs were seepage plus drip irrigation at a volume of 28 and 14 acre-inches/acre per season, respectively, and seepage irrigation at a volume of 28 acre-inches/acre per season. Each season was 11 weeks long from the time of transplanting to the last harvest. Nitrogen fertilization programs consisted of preplant $\mathrm{N}$ rates of 200,250 , and $300 \mathrm{lb} /$ acre $\mathrm{N}$. Treatments were arranged in a split-plot design with four replications, where the irrigation programs were the main plots and the $\mathrm{N}$ rates were the subplots. The source for 
preplant $\mathrm{N}$ was ammonium nitrate $\left(\mathrm{NH}_{4} \mathrm{NO}_{3}\right)$, which was applied during prebedding in two 1 -inch-deep bands on bed tops, 12 inches apart. Other plant nutrients were injected using recommended sufficiency levels during the last irrigation cycle (between 1300 and 1500 HR) three times per week with a hydraulic injector (Dosatron, Clearwater, FL). Potassium was drip-injected to all plots three times per week using potassium chloride as source and it was applied at rates of $1.5,2.0$, and $2.5 \mathrm{lb} /$ acre per day from transplanting to 2 WAT, from 3 to 5 WAT, and from 6 to 11 WAT, respectively. A total volume of $\approx 1$ acre-inch/acre was used to inject $\mathrm{K}$ throughout the season. Application of phosphorus (P) and calcium (Ca) was not necessary because the experimental site had sufficient concentrations of these nutrients ( $>250$ ppm $\mathrm{P}$ and $>1000$ $\mathrm{lb} /$ acre $\mathrm{Ca}$ ) as revealed by soil tests conducted 1 month before planting. Micronutrients, such as iron, zinc, boron, and manganese were applied under nonlimiting conditions following current fertilization recommendations for tomatoes (Olson et al., 2006). The crop was staked at 3 WAT and tied three times at 3, 5, and 7 WAT. Current recommendations for insect and disease control were followed (Olson et al., 2006).

Experimental units were $50 \mathrm{ft}$ long, equivalent to 25 tomato plants per plot, with a 5 -ft-long nontreated buffer zone at the end of each plot, which is sufficient distance between plots to avoid confounding results based on the poor lateral water movement in west-central Florida spodosols. Plant height was measured at 5 and 7 WAT in 2006 and at 5 WAT in 2007 by measuring the vertical distance between the bed tops and the highest opened growing point. Petiole samples were extracted 8 WAT from between 10 and 15 mature petioles per plot collected from recently open mature leaves in each plot. The sap was extracted from 8 to 10 (0.5-inch long) petiole sections using a kitchen garlic presser and the samples were measured for $\mathrm{NO}_{3}{ }^{-}$concentrations with a $\mathrm{NO}_{3}{ }^{-}$-ion analyzer (Cardy Meter; Horiba Group, Kyoto, Japan). Marketable tomato fruit were harvested twice (9 and 11 WAT) in the mature green stage and were graded following current market standards as extralarge, large, and medium fruit (Sargent et al., 2005). Resulting data were analyzed with the general linear model procedure (Statistix Analytical Software, Tallahassee, FL) to determine the significance $(P<0.05)$ of the individual factors (irrigation programs and $\mathrm{N}$ rates), and their interactions. $\mathrm{N}$ rates were separated using standard errors of the treatment means.

\section{Results and discussion}

Data from two seasons were combined because the season by treatment interactions for each variable were not significant. During both planting seasons, the treatments did not affect tomato plant height (data not shown). $\mathrm{NO}_{3}{ }^{-}$petiole concentrations measured at 8 WAT were significantly affected by the irrigation program by $\mathrm{N}$ rate interaction (Fig. $1)$. In plots irrigated with seepage alone, the lowest value (381 ppm of $\mathrm{NO}_{3}{ }^{-}$) was found when a preplant $\mathrm{N}$ rate of $200 \mathrm{lb} /$ acre was applied, increasing steadily with the $\mathrm{N}$ rates. The highest $\mathrm{NO}_{3}{ }^{-}$petiole value was 535 ppm when $300 \mathrm{lb} /$ acre $\mathrm{N}$ were incorporated in the soil. These data indicated that $\mathrm{NO}_{3}{ }^{-}$concentrations were $16 \%$ and $29 \%$ higher in plots treated with 250 and $300 \mathrm{lb} /$ acre $\mathrm{N}$, respectively, than in those that received only $200 \mathrm{lb} /$ acre $\mathrm{N}$. In contrast, plots irrigated with seepage plus drip irrigation showed no significant differences among $\mathrm{N}$ rates with $\mathrm{NO}_{3}{ }^{-}$petiole concentrations ranging between 505 and 530 ppm. There was no significant $\mathrm{NO}_{3}^{-}$petiole concentration difference between the two irrigation programs at the highest $\mathrm{N}$ rate, but the $\mathrm{NO}_{3}{ }^{-}$concentrations with seepage plus drip were consistently higher than those in the seepage treatments within 200 and 250 lb/acre $\mathrm{N}$.

The interaction between irrigation programs and $\mathrm{N}$ rates influenced the total marketable fruit weight and the weight of extra-large fruit (Figs. 2 and 3 ). In contrast, there was no treatment effect on the large and medium fruit categories (data not shown). For the total marketable fruit weight, there were no differences among $\mathrm{N}$ rates in those plots irrigated with the seepage plus drip combination, ranging between 23.8 and 25.9 tons/acre. However, there was a

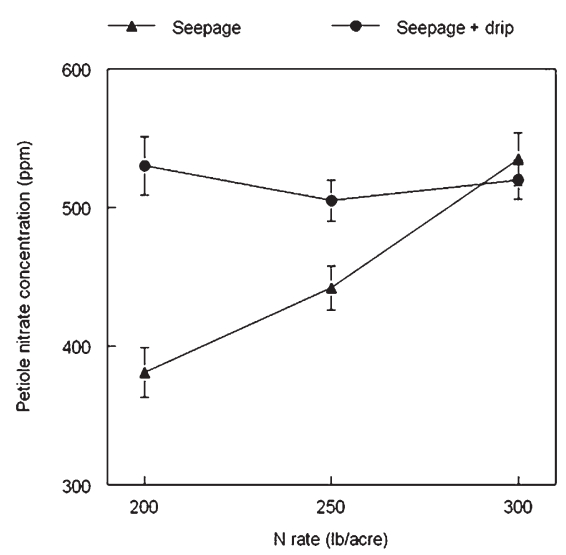

Fig. 1. Effects of nitrogen $(\mathrm{N})$ rates and irrigation programs on tomato petiole nitrate $\left(\mathrm{NO}_{3}{ }^{-}\right)$concentration at 8 weeks after transplanting. Seepage alone provided 28 acre-inches/acre per season and seepage + drip provided $28+$ 14 acre-inches/acre per season. Vertical bars represent the SE; 1 acre-inch/acre = $254.0 \mathrm{~m}^{3} \cdot \mathrm{ha}^{-1} ; 1 \mathrm{lb} /$ acre $=1.1209$ $\mathrm{kg} \cdot \mathrm{ha}^{-1}$.

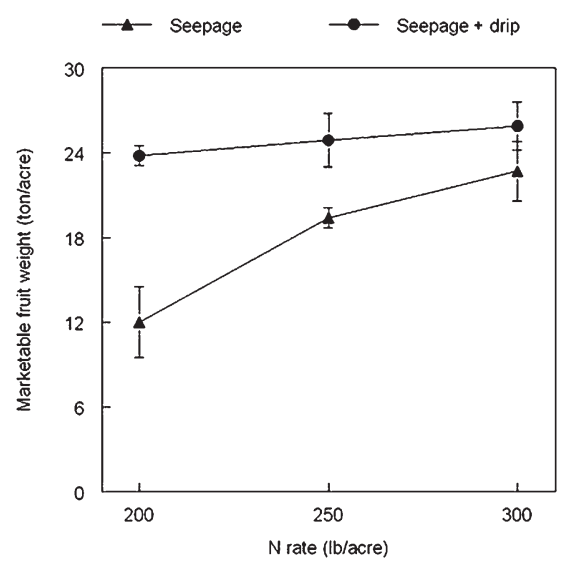

Fig. 2. Effects of nitrogen $(\mathrm{N})$ and irrigation programs on tomato marketable fruit weight. Seepage alone provided 28 acre-inches/acre per season and seepage + drip provided $28+$ 14 acre-inches/acre per season. Vertical bars represent the SE; 1 acre-inch/acre $=$ $254.0 \mathrm{~m}^{3} \cdot \mathrm{ha}^{-1} ; \mathrm{l} \mathrm{lb} /$ acre $=1.1209$ $\mathrm{kg} \cdot \mathrm{ha}^{-1} ; 1$ ton $/$ acre $=2.2417 \mathrm{t} \cdot \mathrm{ha}^{-1}$.

significant $\mathrm{N}$ effect in plots receiving only seepage irrigation with marketable fruit weight almost doubling from 12.0 to 22.7 tons/acre when applying 200 and $300 \mathrm{lb} /$ acre $\mathrm{N}$, respectively. The same trend occurred when comparing the marketable fruit weight between irrigation treatments within the $200 \mathrm{lb} /$ acre $\mathrm{N}$ level, whereas there was a $28 \%$ yield difference within the $250 \mathrm{lb} /$ acre $\mathrm{N}$ level between the two irrigation programs. 


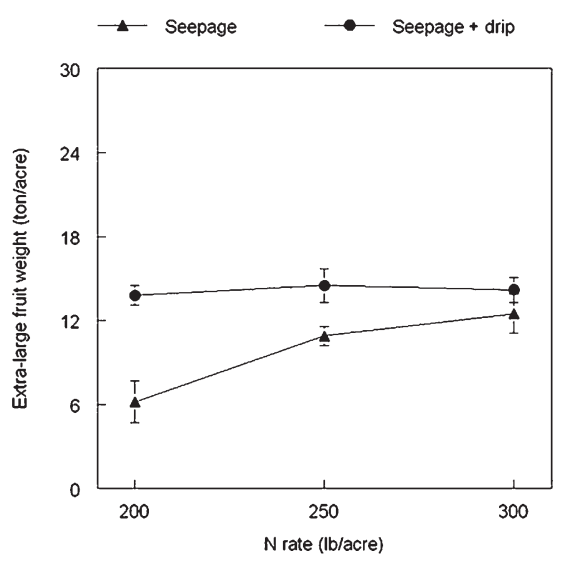

Fig. 3. Effects of nitrogen $(\mathrm{N})$ and irrigation programs on tomato extralarge fruit weight. Seepage alone provided 28 acre-inches/acre per season and seepage + drip provided $28+$ 14 acre-inches/acre per season. Vertical bars represent the SE; 1 acre-inch $/$ acre $=$ $254.0 \mathrm{~m}^{3} \cdot \mathrm{ha}^{-1} ; \mathrm{l} \mathrm{lb} /$ acre $=1.1209$ $\mathrm{kg} \cdot \mathrm{ha}^{-1} ; 1$ ton $/$ acre $=2.2417 \mathrm{t} \cdot \mathrm{ha}^{-1}$.

Both irrigation programs had equivalent performance when $300 \mathrm{lb} /$ acre $\mathrm{N}$ was applied.

With regards to extra-large fruit weight, increasing $\mathrm{N}$ rates above 200 $\mathrm{lb} /$ acre failed to increase yields when using the seepage plus drip irrigation program, with average values of 14.2 tons/acre (Fig. 3). However, there was a response to $\mathrm{N}$ rates in plots irrigated only with the seepage method. Extra-large fruit weight rose from 6.2 to 10.9 tons/acre as $\mathrm{N}$ rates increased from 200 to $250 \mathrm{lb} /$ acre. There was no significant effect on extra-large fruit weight with $\mathrm{N}$ rates higher than $250 \mathrm{lb} /$ acre. Similarly, there was no difference on extra-large fruit yield at the $300 \mathrm{lb} /$ acre $\mathrm{N}$ level across the two irrigation programs.

Results showed two very distinct responses of the tomatoes to the combinations of irrigation programs and preplant $\mathrm{N}$ rates. Petiole sap $\mathrm{NO}_{3}{ }^{-}$concentration, extra-large fruit weight, and total marketable fruit weight significantly increased as $\mathrm{N}$ rates increased in plots irrigated with seepage alone. With the exception of an $\mathrm{N}$ rate of $300 \mathrm{lb} /$ acre, fruit yield and $\mathrm{NO}_{3}^{-}$petiole concentrations were always lower with seepage alone in comparison with seepage plus drip irrigation treatments. This indicates that 28 acre-inches/acre per season produced the highest total yield with an $\mathrm{N}$ rate of $300 \mathrm{lb} / \mathrm{acre}$. In contrast, the crop reached its highest total yield with only $200 \mathrm{lb} /$ acre when seepage plus drip irrigation were used at volumes of 28 and 14 acre-inches/acre per season, respectively. This finding indicated that adding drip irrigation to the production system likely improved $\mathrm{N}$ absorption and utilization, as shown by the significant differences in the $\mathrm{NO}_{3}{ }^{-}$petiole concentrations within the $200 \mathrm{lb} /$ acre $\mathrm{N}$ level. At that level, petiole $\mathrm{NO}_{3}{ }^{-}$concentration was deficient for crop production $(<400$ ppm at 8 WAT) with only seepage irrigation (Olson et al., 2006). In contrast, the $\mathrm{NO}_{3}-\mathrm{N}$ petiole concentration was $>500 \mathrm{ppm}$ in plots irrigated with the combination of seepage plus drip.

This research shows an interesting trade-off in the use of $\mathrm{N}$ and irrigation water for tomato production. While adding drip irrigation to tomato lands under seepage would increase water use from 28 to 42 acreinches/acre per season, preplant $\mathrm{N}$ rates could be reduced from 300 to $200 \mathrm{lb} /$ acre without significant yield reduction. This has important economic and environmental implications on crop production. On the economic side, reducing $\mathrm{N}$ rates from 300 to $200 \mathrm{lb} /$ acre in fields irrigated with the combination of both systems may reduce fertilizer costs by $\$ 168 /$ acre, assuming current fertilizer costs (USDA, 2009), but it would increase water use by $50 \%$, which means longer pumping times and thus more electricity or diesel fuel for that purpose. Environmentally speaking, reducing $\mathrm{NO}_{3}^{-}$leaching to groundwaters may be achieved if lower $\mathrm{N}$ rates are used. Reduced $\mathrm{N}$ rates are only feasible in tomato fields irrigated with seepage plus drip. Further research should concentrate on examining the effect of reducing seepage volumes in combination with drip irrigation under increasing $\mathrm{N}$ rates on tomato.

The results presented disagree with the current $\mathrm{N}$ recommendations for producing tomatoes in Florida under seepage irrigation, which establishes that $200 \mathrm{lb} /$ acre $\mathrm{N}$ are needed (Olson et al., 2006). This rate assumes beds are $6 \mathrm{ft}$ on-centers (7260 linear $\mathrm{ft}$ of beds per acre), which is equivalent to $240 \mathrm{lb} /$ acre $\mathrm{N}$ in the 5 - $\mathrm{ft}$ bed system (8712 linear $\mathrm{ft}$ of bed per acre). Under the conditions of this study, a rate of $300 \mathrm{lb} /$ acre $\mathrm{N}(340 \mathrm{lb} /$ acre $\mathrm{N}$ in the 5 - $\mathrm{ft}$ bed system) is needed to produce tomatoes with seepage irrigation alone and it was proven that $200 \mathrm{lb} /$ acre $\mathrm{N}$ do not satisfy crop requirement for high yields. More studies are needed particularly to determine the appropriate amount of $\mathrm{N}$ fertilizer for seepage-irrigated tomatoes. In addition, the role of drip irrigation can play in reducing $\mathrm{N}$ requirements and groundwater contamination should be examined.

\section{Literature cited}

Bar-Yosef, B. 1977. Trickle irrigation and fertilization of tomatoes in sand dunes. Water, $\mathrm{N}$ and $\mathrm{P}$ distribution in the soil land uptake by plants. Agron. J. 69:486491.

Bouman, B.A.M., M.C.S. Wopereis, M.J. Kropff, H.F.M. ten Berge, and T.P. Tuong. 1994. Water use efficiency of flooded rice fields, II. Percolation and seepage losses. Agr. Water Manage. 26:291304.

Carpenter, S.R., N.F. Caraco, D.L. Correll, R.W. Howarth, A.N. Sharpley, and V.H. Smith. 1998. Nonpoint pollution of surface waters with phosphorus and nitrogen. Ecol. Appl. 8:559-568.

Finkl, C.W. and R.H. Charlier. 2003. Sustainability of subtropical coastal zones in southeastern Florida: Challenges for urbanized coastal environments threatened by development, pollution, water supply, and storm hazards. J. Coast. Res. 19:934-943.

Florida Department of Environmental Protection. 2008. Integrated water quality assessment for Florida: 2008 305(b) report and 303(d) list update. 26 Nov. 2008. <http://www.dep.state.fl.us/water/ docs $/ 2008$ Integrated_Report.pdf $>$.

Florida Springs Task Force. 2000. Florida's springs: Strategies for protection and restoration. 26 Nov. 2008. <http:// www.dep.state.fl.us/springs/reports/ index.htm $>$.

Locascio, S.J. 2005. Management of irrigation for vegetables: Past, present, and future. HortTechnology 15:482-485.

Olson, S.M., W.M. Stall, M.T. Momol, S.E. Webb, T.G. Taylor, S.A. Smith, E.H. Simonne, and E. McAvoy. 2006. Tomato production in Florida, p. 407-426. In: S.M. Olson and E.H. Simonne (eds.). Vegetable production handbook for Florida, 2006-2007. Inst. Food Agr. Sci. Publ., Univ. Florida, Gainesville.

Pitts, D.J., A.G. Smajstrla, D.Z. Haman, and G.A. Clark. 2002. Irrigation costs for 
tomato production in Florida. 23 Mar. 2009. <http://edis.ifas.ufl.edu/AE010>.

Sargent, S.A., J.K. Brecht, and T. Olczyk. 2005. Handling Florida vegetable series: Round and Roma tomato types. 23 Mar. 2009. <http://edis.ifas.ufl.edu/VH079>.

Simonne, E.H. 2004. Drip irrigation management for tomato. 2004 Florida Tomato Inst. Proc., 6-7.

Simonne, E.H. and B. Morgant. 2005. Denitrification in seepage-irrigated vegetable fields in south Florida. 23 Mar. 2009. <http://edis.ifas.ufl.edu/document_hs248>.

Simonne, E.H., M.D. Dukes, and D.Z. Haman. 2007. Principles and practices of irrigation management for vegetables, $\mathrm{p}$ 33-39. In: S.M. Olson and E.H. Simonne (eds.). Vegetable production handbook for Florida, 2007-2008. Inst. Food Agr. Sci. Publ., Univ. Florida, Gainesville.

Smajstrla, A.G. and D.Z. Haman. 2005. Irrigated acreage in Florida: A summary through 1998. 23 Mar. 2009. <http:// edis.ifas.ufl.edu/AE150>.

Smajstrla, A.G., B.J. Boman, G.A. Clark, D.Z. Haman, D.S. Harrison, F.T. Izuno, D.J. Pitts, and F.S. Zazueta. 2002. Efficiencies of Florida agricultural irrigation systems. 23 June 2009. <http://edis.ifas. ufl.edu/AE110>.
Stanley, C.D. and G.A. Clark. 2003. Effect of reduced water table and fertility levels on subirrigated tomato production in southwest Florida. 23 Mar. 2009. <http:/ edis.ifas.ufl.edu/document_ss429>.

U.S. Department of Agriculture. 2007. Vegetables: 2006 summary. 6 Mar. 2007. <http://usda.mannlib.cornell.edu/ usda/nass/VegeSumm//2000s/2006/ VegeSumm-01-27-2006.pdf>

U.S. Department of Agriculture. 2009. U.S. fertilizer use and price. 11 May 2009. <http://www.ers.usda.gov/Data/ FertilizerUse> 